\title{
The Effect of Duration of Use of Depomedroxyprogesterone Acetate on the Thickness of the Vaginal Epithelium of Mice
}

\author{
Nora Veri ${ }^{1 *}$, Cut Mutiah ${ }^{1}$, Dewita Dewita ${ }^{1}$, Henniwati Henniwati ${ }^{1}$, Fazdria Fazdria ${ }^{1}$, Lia Lajuna ${ }^{2}$, T Salfiyadi Salfiyadi ${ }^{3}$ \\ ${ }^{1}$ Department of Midwifery, Ministry of Health Polytechnic of Langsa, Aceh, Indonesia; ${ }^{2}$ Department of Midwifery, Polytechnic of Health, \\ Ministry of Health, Aceh, Indonesia; ${ }^{3}$ Department of Dental Nursing, Polytechnic of Health, Ministry of Health, Aceh, Indonesia
}

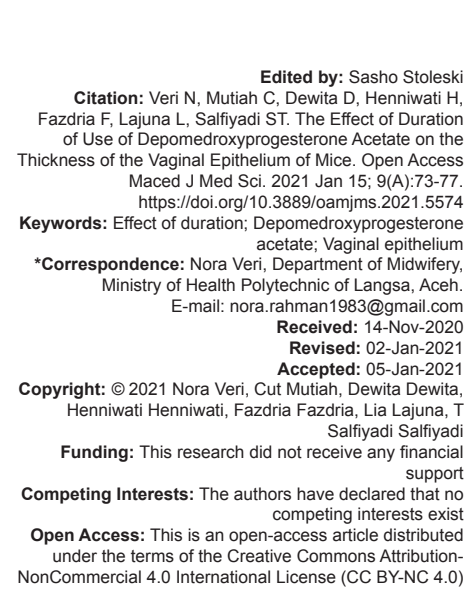

\section{Introduction}

Sustainable development (SDGs), namely, ensuring good health and well-being, furthermore achieving gender equality and empowering all women and girls include universal sexual and reproductive health. Both developed and developing countries around the world have shown increasing use of contraception to control populations [1]. Indonesia is a developing country with the most populous population in Southeast Asia. This situation encourages the government to establish policies regarding population control, namely, by establishing a family planning program (KB). Family planning can also help achieve other SDGs by enabling women to remain in employment or complete education, reducing poverty, and gender inequality [2], [3]. Although contraception has been used globally, contraceptive use remains lower in developing countries [4]. In Indonesia, the prevalence of contraceptive use is still low and varies between provinces, economic status, education level, and location of residence [5]. Injectable contraceptives, including DMPA, are gaining popularity because of their ease of use, effectiveness, and affordability [6]. Birth control in family planning is used to control the time between pregnancies. Although the number of family planning users is increasing, the determinant of contraceptive use in married women in Indonesia is still insufficient [7]. There are several types of contraceptive methods in family planning. The use of contraceptive methods in 2012 showed that most family planning participants chose to use injection contraception [8]. The highest percentage of active contraceptive participants according to contraceptive methods was injection $(46.84 \%)$, followed by pills $(25.13 \%)$, intra-uterine device (IUD) $(11.53 \%)$, implants $(9.17 \%)$, female operative (MOW) $(3.49 \%)$, condoms (3.13\%), and male 
operative method $(0.70 \%)$ [9] Injectable contraceptives include depomedroxyprogesterone acetate (DMPA) that is gaining popularity because of its ease of use, effectiveness, and affordability [1]. DMPA is one of the most effective contraceptive methods because of the various benefits that can be obtained including not affecting sexual relations, does not affect breast milk, and has few side effects [10]. The main side effects of DMPA contraception at 6 months are menstrual disorders/bleeding patterns $(93.60 \%)$, weight gain $(48 \%)$, pain in joints $(24 \%)$, and vaginal dryness $(10.4 \%)$ [10]. The use of DMPA has the disadvantage Human Immunodeficiency Virus (HIV) infection. $\mathrm{HIV}$ infection in women is mostly found in women of productive age. Eleven injectable contraceptives are responsible for 27,000-130,000 HIV-1 infections per year globally [11]. It remains controversial because several studies have failed to observe the overall effect of hormonal contraception on the incidence of HIV-1 infection or disease progression [12]. Biologically, women are more vulnerable than men. It is because sexual intercourse usually causes a woman's vagina to become blistered, and HIV enters through the wound. The concentration of HIV in the seminal fluid is much higher than the concentration of HIV in the vaginal fluid, which causes HIV and STD transmission to be more effective from men to women than vice versa. Women also face a greater risk associated with violence, such as rape, incestuous intercourse, and forced sexual intercourse, not through the vagina, such as through the rectum, where bleeding occurs more easily [13]. Women have a greater chance of being infected with HIV through sexual contact than men. The medical vulnerability of women is probably because the inner lining of the female genitalia is more prone to blisters during sexual intercourse than the inner lining of men. It is through this blistered part that the HIV penetrates and enters the bloodstream. HIV infection in women is mostly found in women of productive age [8]. Based analyze the effect of DMPA use on the thickness of the vaginal epithelium of mice. of increasing the Human Papilloma Virus and the on the background, the purpose of this study was to

of mice. This study used mice with a completely randomized design method. The project was conducted at the Pharmacology Laboratory and the Anatomical Pathology Laboratory, FKH Unsyiah. The role of the researcher starts from selecting experimental animals, assisting in surgery, and analyzing using Image $\mathrm{J}$ software. Mice were obtained from the Pharmacology Laboratory of FK Unsyiah and were selected as research subjects because they were easy to maintain and were relatively healthy animals and suitable for use in various types of research.

Balb/c mice were divided into four categories: Control Group 1: Injection of normal saline for 10 days. Control Group 2: Injection of normal saline for 15 days. Treatment Group 1: DMPA dose $0.39 \mathrm{mg} / \mathrm{mouse} /$ day for 10 days. Treatment Group 2: DMPA dose $0.39 \mathrm{mg} / \mathrm{mouse} /$ day for 15 days. Inclusion criteria for study subjects: Strain Balb/c, female gender, age 2 months, weight 18-35 g, healthy condition, and no visible anatomical disability. Exclusion criteria: Mice died during the research process. The number of experimental animal subjects for each group was six mice. To anticipate if there are experimental animals that die during the adaptation and treatment period. Hence, the group is added $10 \%$ of the number of experimental animals, namely, one as a reserve so that the number of experimental animals in each experimental group is 28 . The data collection technique in this study was observed with a light microscope to calculate the average thickness of the vaginal epithelium of mice injected with DMPA in the four groups. In this study, the data analysis technique was carried out in five counting stages. There are five consecutive stages, namely, (1) normality test of sample data with the Shapiro-Wilk test, (2) homogeneity test of variance with the Levene test, (3) to compare the thickness of the vaginal epithelium in each of the two treatment groups an independent t-test was performed. All calculations were carried out with the aid of the SPSS for Windows 19.0 software.

\section{Results}

\section{Methods}

The research design used in this study was true experimental with a post-test only control group design approach. The post-test only control group design approach is that observations are made after the intervention is given. In this study, the treatment was carried out at a dose of $0.39 \mathrm{mg} / \mathrm{mouse} /$ day DMPA exposure in mice. The phenomenon (response) that occurs due to the treatment is observed after the treatment is complete. The phenomenon observed in this study was the thickness of the vaginal epithelium

\section{Vaginal epithelial thickness}

The results of observing the number of spiral arteries with a light microscope and analyzed using Olivia software (Image 1). The vaginal epithelium, as illustrated below:

\section{Parametric prerequisite test results}

They are testing the comparison of the average thickness of vaginal epithelium in the control group and treatment group for 10 days, and the 


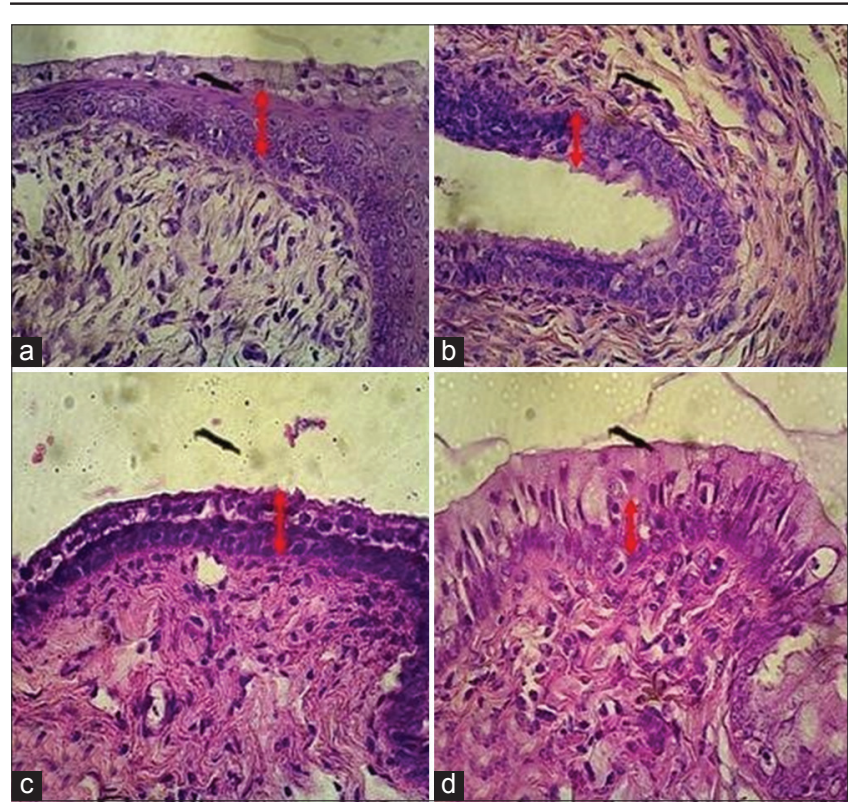

Image 1: Observation of vaginal thickness using a light microscope and Olivia software. The red color indicates the thickness of the vagina (indicated by an arrow). The differences in the mean total vaginal thickness are shown in pictures $A, B, C$, and $D$. Captions: (a) Control group 10 days (without treatment), (b) 10 days DMPA exposure group, (c) 15 days control group, (d) the DMPA exposure group was 15 days

control group and treatment group 15 days using the independent t-test. However, before the independent t-test is carried out, the assumption testing based on the parametric test is carried out. Namely, the normality assumption is carried out using the Shapiro-Wilk test. The assumption of normality is said to be fulfilled if the $\mathrm{p}$-value of the calculation results is more significant than $\alpha=0.05$. Using SPSS software, the following normality assumption test results are obtained:

Based on Table 1, the variable vaginal epithelial thickness obtained a $p$-value of more than $\alpha=0.05$ $(p>0.05)$. This value indicates that the assumption of normality in the 10-day vaginal epithelial thickness variable has been fulfilled. Likewise, the variable thickness of the vaginal epithelium thickness for 15 days, the $p$-value was more than $\alpha=0.05(p>0.05)$. The normality assumption test shows that both variables have been fulfilled.

Table 1: Normality assumption test

\begin{tabular}{lllll}
\hline Group & Duration of DMPA exposure & Coefficient & p-value & Information \\
\hline 10 days of DMPA & Control & 0.868 & 0.218 & Normal \\
exposure & Treatment & 0.901 & 0.377 & Normal \\
15 days of DMPA & Control & 0.953 & 0.763 & Normal \\
exposure & Treatment & 0.899 & 0.367 & Normal \\
\hline
\end{tabular}

\section{The assumption of homogeneity of variety is tested using the Levene test}

The assumption of homogeneity of variance is said to be fulfilled if the $p$-value of the calculation result is more significant than $\alpha=0.05$. The following are the results of testing the assumption of homogeneity of variety using the help of SPSS software:
Based on Table 2, in testing the assumption of homogeneity of the variability of the number of endothelial cells, the $p$-value is more significant than $\alpha=0.05(p>0.05)$ which indicates that the assumption of homogeneity of the variety of the number of endothelial cells has been fulfilled.

Table 2: Variety homogeneity test

\begin{tabular}{llll}
\hline Variable & Coefficient & $\mathrm{p}$-value & Information \\
\hline The thickness of the vaginal epithelium in the & 0.242 & 0.633 & Homogeneous \\
$\begin{array}{l}\text { 10-day group } \\
\text { The thickness of the vaginal epithelium in the }\end{array}$ & 1.054 & 0.329 & Homogeneous \\
\begin{tabular}{l} 
15-day group \\
\hline
\end{tabular}
\end{tabular}

\section{Testing the effect of 10 days and 15 days} of DMPA exposure on vaginal epithelial thickness

The following are the results of testing the effect of DMPA on the thickness of the vaginal epithelium using the independent t-test.

Based on Table 3, it is shown that the average thickness of vaginal epithelium exposure to DMPA for 10 days in the control group is $182536.33 \pm 5773.465$. In the treatment group exposure to DMPA for 10 days, the thickness of the vaginal epithelium was 168322.33 \pm 7611.300 . Descriptively, it was shown that the mean vaginal epithelial thickness of the control group with 10 days of DMPA exposure was higher than the 10-day DMPA exposure treatment group or in other words, it was descriptively proven that there was thinning of the vaginal epithelium due to exposure to DMPA. Using the independent t-test, the $p$-value was $0.005(p<0.05)$. From this test, it is shown that there is a significant difference in the mean vaginal epithelium between the control group and the DMPA exposure treatment group for 10 days. Table 3 also shows that the mean vaginal epithelial thickness in the 15-day DMPA exposure group in the control group was $177242.83 \pm 9689.558$. In the 15-day DMPA exposure treatment group, the thickness of the vaginal epithelium was $138674.83 \pm 17176.124$. Descriptively, it was shown that the mean vaginal epithelial thickness in the control group was higher than the treatment group with 15 days of DMPA exposure or in other words, it was descriptively proven that there was thinning of the vaginal epithelium due to 15 days of exposure to DMPA. Using the independent t-test, the $p$-value was $0.001(p>0.05)$. From this test, it is shown that there is a significant difference in the mean vaginal epithelium between the control group and the 15-day treatment group.

Table 3: Differences in average vaginal epithelial thickness due to DMPA exposure with independent $t$-test

\begin{tabular}{lllc}
\hline DMPA exposure & Group & Mean \pm SD $(\%)(\mu \mathrm{m})$ & p-value \\
\hline $\begin{array}{llll}\text { DMPA days } \\
10\end{array}$ & $\begin{array}{l}\text { Control } \\
\text { Treatment }\end{array}$ & $182536.33 \pm 5773.465$ & 0.005 \\
& & $168322.33 \pm 7611.300$ & \\
DMPA days & Control & $177242.83 \pm 9689.558$ & 0.001 \\
15 & Treatment & $138674.83 \pm 17176.124$ & \\
\hline
\end{tabular}

Table 4 shows the difference in the mean value of vaginal epithelial thickness between 10 
day and 15-day DMPA exposure. The difference in vaginal epithelial thickness in the two treatment groups with 10 days and 15 days of DMPA exposure was significantly different, which was indicated by a $p$-value of 0.003 ( $p<0.05)$. It means that the longer the exposure to DMPA and the thinner the thickness of the vaginal epithelium.

Table 4: Difference in average vaginal epithelial thickness due to duration of DMPA exposure with independent t-test in the treatment group

\begin{tabular}{lll}
\hline Duration of DMPA exposure & Mean \pm SD $(\%)$ & p-value \\
\hline 10-day exposure & $168322.33 \pm 7611.300$ & 0.003 \\
15-day exposure & $138674.83 \pm 17176.124$ & \\
\hline
\end{tabular}

\section{Discussion}

The finding indicated that exposure to DMPA will dilute the thickness of the vaginal epithelium due to exposure to DMPA for 10 days and 15 days. The difference in the thickness of the vaginal epithelium in the two groups treated with DMPA exposure for 10 days and 15 days was significantly different, which was indicated by a p-value of 0.003 ( $p<0.05$ ). The prolonged exposure to DMPA results in the thinning of the vaginal epithelial thickness. In some studies, DMPA can attenuate vaginal epithelium to the level of the luteal phase and increase the number of HIV target cells in vaginal tissue although other studies have found no effect of DMPA on cells [14]. The results also found that the average vaginal epithelial thickness of the DMPA exposure control group at 10 days was higher than the 10-day DMPA exposure treatment group. The independent t-test results obtained a $p=0.005$ $(p<0.05)$, which means that there is a significant difference in the average vaginal epithelium between the control group and the DMPA exposure treatment group for 10 days. There is thinning of the vaginal epithelium due to exposure to DMPA. Vaginal epithelial thinning or Langerhans cell count did not differ between long-term DMPA users and copper-bearing IUD users who had never used DMPA [15]. Studies using nonhuman primate models indicate that DMPA increases the risk of acquisition of simian immunodeficiency virus through vaginal exposure [16], [17]. DMPA suppresses ovulation, where the active component of DMPA, medroxyprogesterone binds to glucocorticoid receptors and has a more substantial immunosuppressive effect than progesterone [18]. The use of DMPA increases the incidence of endothelial dysfunction, which is characterized by reduced flow-mediated dilation in the brachial artery [19]. The contraceptive component of DMPA has been shown to suppress systemic immune regulators, reduce cytokine production by plasmacytoid dendritic cells, and increase HIV-1 replication in blood mononuclear cells [14]. The decrease in estrogen levels frequently occurs with the length of time using DMPA.
These levels are the same as estrogen levels in the follicular phase of the menstrual cycle. Long-term use of progesterone contraceptives can change the vascular structure of the vagina and the morphology of vaginal tissue, along with the occurrence of oxidative stress and apoptosis due to a deficiency in the endogenous hormone estrogen [20]. The decrease in estradiol occurs with prolonged use of DMPA contraceptives and results in vaginal dryness and dyspareunia and can increase body weight and organ weight. DMPA can also make the endometrium secretory, and if used longterm, the endometrial lining becomes very thin [21]. DMPA reduces the risk of iron deficiency anemia, pelvic inflammatory disease, ectopic pregnancy, and disorders associated with uterine fibroids, pain symptoms associated with endometriosis, and the risk of endometrial cancer [22].

\section{Conclusion}

There was a difference in the mean vaginal epithelial thickness between the control group and 10 days of DMPA exposure. There was a difference in the mean vaginal epithelial thickness between the control group and 15 days of DMPA exposure. The longer the exposure to DMPA, the thinner the thickness of the vaginal epithelium is.

\section{References}

1. World Health Organization. Keluarga Berencana/Kontrasepsi. Geneva: World Health Organization; 2019.

2. Cates W Jr., Karim QA, El-Sadr W, Haffner DW, KalemaZikusoka G, Rogo K, et al. Global development. Family planning and the millennium development goals. Science. 2010;329(5999):1603. https://doi.org/10.1126/science.1197080 PMid:20847233

3. Habumuremyi PD, Zenawi M. Making family planning a national development priority. Lancet. 2012;380(9837):78-80. https://doi. org/10.1016/s0140-6736(12)60904-0 PMid:22784539

4. United Nations, Department of Economic and Social Affairs, Population Division World Contraceptive Use 2012, UN Report; 2012.

5. BPS, BKKBN, Kemenkes, ICF. Survei Demografi dan Kesehatan Indonesia. Jakarta: BPS; 2012.

6. Affandi B. Long-acting progestogens. Best Pract Res Clin Obstet Gynaecol. 2002;16(2):169-79.

PMid:12041960

7. Gafar A, Suza DE, Efendi F, Has EM, Pramono AP, Susanti IA Determinants of contraceptive use among married women in Indonesia. F1000Res. 2020;9:193. https://doi.org/10.12688/ f1000research.22482.1

PMid:32269768 
8. Kementerian Kesehatan Republik Indonesia. Profil Kesehatan Indonesia 2012. Jakarta: Kementerian Kesehatan Republik Indonesia; 2012. https://doi.org/10.7454/jki.v19i3.469

9. Veisi F, Zangeneh M. Comparison of two different injectable contraceptive methods: Depo-medroxy progesterone acetate (DMPA) and cyclofem. J Family Reprod Health. 2013;7(3):109-13.

PMid:24971112

10. Gisselquist D. Use of hormonal contraceptives and risk of HIV-1 transmission. Lancet Infect Dis. 2012;12(7):510. https://doi. org/10.1016/s1473-3099(12)70115-9 PMid:22742633

11. Butler AR, Smith JA, Polis CB, Gregson S, Stanton D, Hallett TB. Modelling the global competing risks of a potential interaction between injectable hormonal contraception and HIV risk. AIDS. 2013;27(1):105-13. https://doi.org/10.1097/ qad.0b013e32835a5a52 PMid:23014519

12. Polis CB, Curtis KM. Use of hormonal contraceptives and HIV acquisition in women: A systematic review of the epidemiological evidence. Lancet Infect Dis. 2013;13(9):797-808. https://doi. org/10.1016/s1473-3099(13)70155-5

PMid:23871397

13. Dalimoenthe I. Women in the Grip of HIV / AIDS: A Household Feminist Sociological Study of Housewives. J Komunitas. 2011;5(1):41-8.

14. Chandra N, Thurman AR, Anderson S, Cunningham TD, Yousefieh N, Mauck C, et al. Depot medroxyprogesterone acetate increases immune cell numbers and activation markers in human vaginal mucosal tissues. AIDS Res Hum Retroviruses. 2013;29(3):592-601. https://doi.org/10.1089/aid.2012.0271 PMid:23189932

15. Bahamondes MV, Castro S, Marchi NM, Marcovici M, Andrade LA, Fernandes A, et al. Human vaginal histology in long-term users of the injectable contraceptive depotmedroxyprogesterone acetate. Contraception. 2014;90(2):11722. https://doi.org/10.1016/j.contraception.2014.01.024

\section{PMid:24613369}

16. Hel Z, Stringer E, Mestecky J. Sex steroid hormones, hormonal contraception, and the immunobiology of human immunodeficiency virus-1 infection. Endocr Rev. 2010;31(1):7997. https://doi.org/10.1210/er.2009-0018 PMid:19903932

17. Murphy G. Tissue inhibitors of metalloproteinases. Genome Biol. 2011;12(11):233.

PMid:22078297

18. Jain JK, Li A, Yang W, Minoo P, Felix JC. Effects of mifepristone on proliferation and apoptosis of human endometrium in new users of medroxyprogesterone acetate. Hum Reprod. 2006;21(3):798-809. https://doi.org/10.1093/humrep/dei383 PMid: 16311300

19. Lizarelli PM, Martins WP, Vieira CS, Soares GM, Franceschini SA, Ferriani RA, et al. Both a combined oral contraceptive and depot medroxyprogesterone acetate impair endothelial function in young women. Contraception. 2009;79(1):35-40. https://doi. org/10.1016/j.contraception.2008.07.024

PMid: 19041439

20. Krikun G, Buhimschi IA, Hickey M, Schatz F, Buchwalder L, Lockwood CJ. Long-term progestin contraceptives (LTPOC) induce aberrant angiogenesis, oxidative stress and apoptosis in the guinea pig uterus: A model for abnormal uterine bleeding in humans. J Angiogenes Res. 2010;2:8. https://doi. org/10.1186/2040-2384-2-8

PMid:20423489

21. Walker C, Badawy SZ. Vaginal atrophy following long-term depot medroxyprogesterone acetate use: A case report. Case Rep Obstet Gynecol. 2013;2013:835316. https://doi. org/10.1155/2013/835316 PMid:23533869

22. Haider Z, D'Souza R. Non-contraceptive benefits and risks of contraception. Best Pract Res Clin Obstet Gynaecol. 2009;23(2):249-62.

PMid: 19196552 